\title{
Sorokina K. \\ INVESTIGATION OF CHARACTERISTICS OF DRAIN SYSTEMS OF RAPID FILTERS ON WATER TREATMENT PLANTS
}

Об'єктом дослідження є сучасні конструкції дренажних систем швидких фільтрів. Дренажна розподільча система швидких фільтрів є найважливішим їх елементом, від якого залежить рівномірність збору фільтрату $і$ його якість, а також розподіл промивної води і в цілому ефективність промивки фільтру. Проведено аналіз результатів реконструкиії дренажних систем фільтрів на комплексі водопідготовки «Дніпро» Комунального підприємства «Харківводоканал» (Україна). Проведений у роботі аналіз експлуатаційних показників використання дренажних систем швидких фільтрів дозволяє виявити доиільність їх застосування. Технічні характеристики та досвід експлуатації свідчить, що найбільи перспективними є системи, виготовлені з полімербетону. Існуючі технології дозволяють отримувати пористий полімербетон оптимального складу як в заводських умовах, так $і$ безпосереднъо на об'єкті. В якості наповнювача використовується квариовий пісок - зерна розміром 0,6-1,2 мм, які мають форму близьку до сферичної (окатанні). Кожне зерно покривається шаром полімерного сполучного, при з'єднанні зерен утворюються міжзернові структурні перемички. Після завершення процесу полімеризації утворюється матеріал з регулярною структурою із розгалуженою мережею порових каналів. Висока гладкість каналів, як результат покриття полімерною плівкою, забезпечує малі значення гідравлічного опору фільтроматеріалу. Своєчасність і повнота регенерації фільтра забезпечує заданий термін його служби. В іншому випадку можливе поступове наростання гідравлічного опору фільтра, яке в подальшому вже не зможе бути зменшено навіть високоінтенсивним промиванням через ущільнення забруднень в порових каналах. Це призведе до необхідності дострокової заміни фільтроелементів. Застосування полімербетонних дренажних систем дозволить відмовитися від гравійних шарів, які підтримують, уникнути засмічення дренажу, знизити витрату промивної води і води на власні потреби в цілому, зменшити витрату електроенергії.

Ключові слова: очищення води, швидкий фільтр, дренажна система, пористий полімербетон, промивка фільтру, промивна вода.

Received date: 14.11.2018

Accepted date: 06.12.2018

Published date: 30.06 .2019
Copyright (C) 2019, Sorokina K. This is an open access article under the CC BY license (http://creativecommons.org/licenses/by/4.0)

\section{Introduction}

In the filters, one of the most important nodes is the drainage system, which is located in the lower zone of the rapid filter. Above the drainage system is a filter layer, mainly of sand. Sometimes anthracite, granite, crushed flasks of metallurgical production, expanded clay, etc. are used. Filtered water is discharged by the drainage system, and when water is supplied to the drainage system, the filtering layer is flushed with water. The choice and effective operation of the drainage system is of great importance, since it must ensure the following functions:

- uniform drainage of the filtrate over the entire filter area;

- preventing the removal of grains of filter material; - uniform distribution over the entire filter area of the wash water (in connection with which these systems are also called distribution).

Uneven flow of washing water supplied at high speeds can lead to uneven and unsatisfactory washing of the filter, cause a shift in the support layers, disrupt the proper operation of the filter, reduce the quality of the filtrate and shorten the filter cycle [1,2].
Currently in operation of treatment plants are various drainage systems of rapid filters [3]:

- tubular with holes of $10-20 \mathrm{~mm}$ and gravel filling with a variable size (increase in size from the upper layers in the direction of the lower). Flushing filters are done only with water;

- cap drainage system with the arrangement of caps on the surface of the overlap, dividing the zone of the filter layer from the zone of the filtrate. During water-air washing, the filtrate zone is also an air zone (upper part). Structures with caps located on the pipes are also provided;

- with sheathed pipes:

a) sheathed polyethylene pipes (standard service life of 5-10 years):

b) sheathed stainless steel pipes.

During water-air flushing, a separate pipe system is used. For practical use, recently due to high performance indicators, drainage systems from polymer concrete slabs have become widespread («porous polymer concrete» gravel in the form of slabs bonded with a binder - epoxy resin). During water-air washing, a separate system of pipes for air is laid [4, 5]. 
For open rapid filters of water treatment plants, two types of drainage systems are recommended:

1) made from prefabricated plates made entirely of porous polymer concrete;

2) made from prefabricated reinforced concrete hole plates, the openings of which are filled with porous polymer concrete [6].

In general, the quality of the filtrate, the flow rate of washing water and electricity, and the cost of water treatment depend on the effective operation of filter drainage systems. In addition, at most operating treatment plants, filters need reconstruction and modernization. Therefore, it is relevant to study the characteristics of filter drainage systems with the formation of recommendations for their use.

Thus, the object of research is the modern design of drainage systems of rapid filters. And the aim of research is analysis of the functional features and performance of drainage systems of rapid filters using a number of criteria.

\section{Methods of research}

To select a rapid filter drainage system, it provides the established indicators of its operation, an analysis of factors characterizing the effectiveness of drainage systems is carried out. The following criteria are selected as the main ones:

- removal of sand and dirt with filtrate;

- uniformity of filtrate collection, distribution of wash water and air over the filter area;

- control of the parameters of the duty cycle and flushing (speed, duration);

- mechanical strength.

The analysis of the results of the reconstruction of filter drainage systems at the Dnipro water treatment complex of the Kharkivvodokanal utility company (Ukraine) is carried out.

\section{Research results and discussion}

The study of operational indicators of the use of drainage systems of rapid filters allows to identify the feasibility of their use. Drainage system of pipes with holes and a base for the filter layer of gravel:

- at present, when designing and choosing as an option, reconstruction has limited use. It is possible to use only with water washing with a limitation of the washing speed, since it is possible to shift the base of the filter layer and gravel;

- during operation, the presence of stagnant zones was noted, which does not exclude the development of bacteria and viruses;

- a sufficiently large flow rate of wash water.

Cap system:

- area of uneven water movement in the lower part

of the filter layer is minimal;

- there is no separate air supply system during flushing;

- high drainage resistance;

- complexity of manufacturing, installation;

- high material consumption;

- rapid wear of both the caps themselves and the overlapping distribution trays.

Drainage system with sheathed pipes:

- laborious manufacture of both plastic and steel;

- changing the size of the slots in plastic pipes dur-

ing installation and operation, which leads to different speeds of movement of water in the filter layer and, as a result, a decrease in the time of the protective action of the filter;

- presence of stagnant zones during operation.

When analyzing the functional features and operational characteristics of the drainage systems of rapid filters, which have been widely used, some systems developed recently have been taken into consideration.

In the tubular system «Polystok» a drainage-supporting frame is provided, which is a two-layer fiberglass structure of cells, between which layers a polymer filter mesh is monolithically fixed. The filter screen is selected taking into account that its cell size is approximately $0.1 \mathrm{~mm}$ less than the minimum recommended size of the loading fractions.

The accumulated operational experience of operating refitted filters has shown that fast filters with a gravelless fiberglass drainage and distribution system provide standard indicators for residual turbidity, color and washing intensity under various filtration modes. Rinsing water is evenly distributed over the entire filter area, which significantly affects the filtration efficiency. In this case, the washing water saving reaches 20-30\% [7].

Among the shortcomings, the lack of reliability of the filter mesh, the possibility of its rapid wear and the presence of stagnant zones should be noted.

Drainage filters of the Ecopolimer Group of Companies (Kharkiv, Ukraine) exclude jet flow in a granular load, which allows increasing the rate of contamination removal and reducing the time required for washing the filter load. The effectiveness of the use of such drainage systems for the reconstruction of wastewater purification filters has been proved [8].

In general, one can note the following advantages of the drainage system [9]:

- improving the efficiency of volume utilization due

to the rejection of supporting gravel layers;

- exception of the removal of the filter load with purified water;

- ensuring a uniform distribution of water during fil-

tration and washing;

- drain filters of adjustable length simplify installation and shorten its time.

Arc-shaped panels of the TRITON drainage system of the European environmental center KREVOX (Vienna, Austria) with a large slit surface made from Vee-Wire tapered wire are suitable for any filtration load.

They have a double filtration surface: the outer one has $\mathrm{V}$-shaped slots, and the inner one has a frame to maintain strength and openings for even distribution of water and air. The supply of water and air during washing and removal of water during filtration is carried out by a channel located at the surface of the filter base. The living cross-section of the grooves of the filtering surface is 20 times larger than the living cross-section of the grooves of the filters from the caps of the system [10].

The speeds of movement of water during filtration in the filter load are uniform. Resistance of the drainage system is 20 times less compared to the cap system. Due to the uniform movement of water in the filter layer, suspended solids are distributed evenly along the height of the filter layer. This increases the filter dirt capacity. The filter cycle increases to 20 hours. Flushing water consumption is minimal.

At the Dnipro Water Treatment Complex (Ukraine), in the block of treatment facilities for water filtration that 
has undergone reagent treatment and preliminary sedimentation, the project provides for quick non-pressure filters with a downward flow of filtered water, in the amount of 24 units. The filtration rate in normal mode is $7.16 \mathrm{~m} / \mathrm{h}$, in forced mode $-7.8 \mathrm{~m} / \mathrm{h}$.

During the operation of the drainage system made from polyethylene sheathing pipes (the standard service life of which is 10 years) as a result of the deformation of the cracks and the destruction of the bridges between them, the filter load is removed when filtering water, the quality of the filtrate deteriorated. When washing the filter on the surface of the washing water visible areas that «gush», there is no uniform distribution of water over the filter area. The time and amount of flushing water increases:

- time - increased from 11 minutes up to 15 minutes;

- flow rate - up to $500 \mathrm{~m}^{3}$ (increase from $8.24 \mathrm{l} / \mathrm{s}$ to $8.41 \mathrm{l} / \mathrm{s}$ from one pipe).

Since 1998, reconstruction of the filter drainage system has begun with the replacement of the drainage system from sheathed polyethylene to polymer concrete and fiberglass. Currently, at the Dnipro water treatment plant block with 24 design filters, two have been repaired, the drainage system has been replaced with polymer concrete on five filters, and the Polystok drainage system has been installed on one filter.

The filter with the drainage system «Polystok» differs from the design one in that instead of filing polyethylene water distribution pipes, laid pipes with a fiberglass frame. The supporting layer of gravel is absent.

The distribution of water and air during washing the filters is slightly worse than in polymer concrete drains (time - up to 13 minutes, flow rate - up to $430 \mathrm{~m}^{3}$ ).

A filter with a polymer concrete drainage system (Fig. 1) is a reservoir with filter loading made of quartz sand or anthracite, in which, unlike design filters, there is no support layer of gravel. Instead, polymer concrete slabs are laid. There are also no water distribution pipes with sheathed polyethylene - instead of them concrete trays are laid. The air distribution system has remained unchanged.

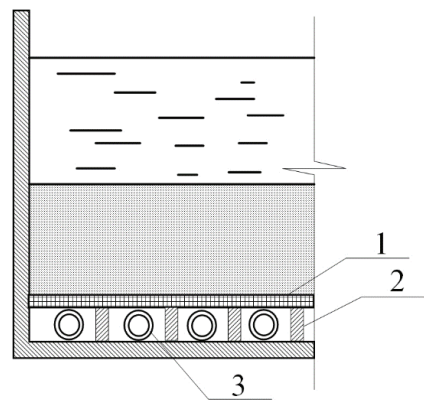

Fig. 1. Fragment of the filter with a polymer concrete drainage system: 1 - polymer concrete slabs; 2 - concrete trays; 3 - air distribution system

Porous polymer concrete is made of aggregate (crushed stone or gravel), which is bonded with an epoxy binder.

Filters with polymer concrete drainage systems have proven themselves on the positive side. During the operation (10-15 years), the following indicators were identified:

- failure of the drainage and air systems was not observed;

- high washing efficiency due to the uniform distribution of water and air over the filter area;
- does not form stagnant zones;

- washing time corresponds to the design - 11-12 minutes;

- water consumption is decreased - 350-400 $\mathrm{m}^{3}$;

- increase in the filtration rate and the duration of the filter cycle;

- removal of sand and pollution above the norm are absent.

But it should be noted that polymer concrete drainage systems are laborious to manufacture. When repairing the air distribution system, it is necessary to remove the plates, with a violation of the integrity of the filter surface. Methods of control of plates before installation do not guarantee their quality.

\section{Conclusions}

During the study, a comparison is made of the characteristics of drainage and distribution systems of various designs installed in filters for treating natural water to drinking quality. It is revealed that the most promising are systems made of polymer concrete. The results of the analysis of the reconstruction of filter drainage systems at the Dnipro water treatment complex of the Kharkivvodokanal utility company confirmed the advantages of polymer concrete drainage systems. The performance indicators of systems with sheathed polyethylene, pipes made from a reinforced plastic frame and polymer concrete slabs are compared. The research results and factors that are determined to characterize the effectiveness of drainage systems will be useful in the design of treatment systems or the development of technical solutions for the reconstruction and modernization of facilities.

\section{References}

1. Meltser, V. Z. (1995). Filtrovalnye sooruzheniia v kommunalnom vodosnabzhenii. Moscow: Stroiizdat, 176.

2. Water treatment manuals. Filtration (1995). Ireland: Published by the Environmental Protection Agency, 80.

3. Zhurba, M. G., Sokolov, L. I., Govorova, Zh. M. (2004). Vodosnabzhenie. Proektirovanie sistem i sooruzhenii. Vol. 2. Moscow: ASV, 496.

4. Wegelin, M. (1996). Surface water treatment by roughing filters A design, Construction and Operation manual. Duebendorf: SANDEC-SKAT, 180.

5. Progulny, V., Ryabkov, M., Borysenko, K., Grachov, I. (2018). Theoretical and experimental study of mud injection porous drainage in filters with floating loading. Technical journal, 12 (4), 231-235. doi: http://doi.org/10.31803/tg-20180410145724

6. Rekomendatsii po primeneniiu poristykh polimerbetonnykh drenazhei v skorykh filtrakh vodoochistnykh stantsii $i$ ustanovkakh zavodskogo izgotovleniia (1989). Moscow: ONTI AKKH, 23.

7. Bezgraviinaia drenazhno-raspredelitelnaia sistema skorogo vodoprovodnogo filtra. POLISTOK. Available at: http://www.polistok. com/bdrs.phtml

8. Ulchenko, V. M. (2010). Doochistka stochnykh vod na filtrakh $\mathrm{s}$ zernistoi zagruzkoi. Vodosnabzhenie $i$ sanitarnaia tekhnika, 12, 34-38.

9. Meshengisser, Iu. M., Sleptsov, G. V., Ulchenko, V. M. (2007). Opyt razrabotki i vnedreniia drenazhno-raspredelitelnykh sistem «Ekopolimer». Vodosnabzhenie i sanitarnaia tekhnika, 10, 17-20.

10. Kinebas, A. K., Feofanov, Iu. A. (2010). Modernizatsiia Zelenogorskoi vodoprovodnoi stantsii - etap realizatsii regionalnoi programmy «Chistaia voda». Vodosnabzhenie $i$ sanitarnaia tekhnika, 9, 38-44.

Sorokina Kateryna, PhD, Associate Professor, Department of Water Supply, Sewerage and Water Treatment, O. M. Beketov National University of Urban Economy in Kharkiv, Ukraine, ORCID: http:// orcid.org/0000-0002-9086-6961, e-mail: kbsorokina@ukr.net 